\title{
Survei larva aedes spp di atas kapal yang bersandar di pelabuhan laut Samudera Bitung Sulawesi Utara
}

\author{
Try G. Wiratama \\ ${ }^{2}$ Victor D. Pijoh \\ ${ }^{2}$ Greta J.P Wahongan
}

\author{
${ }^{1}$ Kandidat Skripsi Fakultas Kedokteran Universitas Sam Ratulangi Manado \\ ${ }^{2}$ Bagian Parasitologi Fakultas Kedokteran Universitas Sam Ratulangi Manado \\ Email: wiratamatry21@gmail.com
}

\begin{abstract}
Infectious disease is the type of disease that is faced by people inside a developing country, including Indonesia. The spread of infectious disease through mosquito as a vector happens almost everywhere. Port is a strategic place for ships and boats from other places to dock that it could be a place for vector from one place to another to transmit. This study aims to see if there is any of Aedes spp's larva found and to know larva density on docked ships at Port of Samudra Bitung North Sulawesi. This was a descriptive study with a cross-sectional design. Twelve ships were checked and 3 of them were positive having larva. Larva density of $\mathrm{HI}$ is $25 \%$, CI is $4.71 \%$, and $\mathrm{BI}$ is $41.66 \%$. Conclusion: This study found the larva of Aedes spp and the larva density has a medium risk of vector transmission on docked ships at Port of Samudra Bitung North Sulawesi. It is advised to do some counseling regarding sanitation of ships to people working in the ship.
\end{abstract}

Keywords: aedes spp, port, ships, house index, container index, breteau index

\begin{abstract}
Abstrak: Penyakit infeksi merupakan jenis penyakit yang paling banyak diderita oleh penduduk di negara berkembang, termasuk di Indonesia. Penyebaran penyakit infeksi melalui vektor serangga khususnya nyamuk sering dijumpai hampir semua tempat. Pelabuhan merupakan tempat strategis untuk kapal-kapal dari berbagai daerah bersandar sehingga bisa menjadi tempat transmisi vektor penyakit dari daerah lain ke daerah lainnya. Penelitian ini bertujuan untuk mengetahui apakah ada larva Aedes spp yang ditemukan dan untuk mengetahui kepadatan larva di atas kapal yang bersandar di Pelabuhan Laut Samudera Bitung Sulawesi Utara. Jenis penelitian ini adalah penelitian deskriptif dengan menggunakan metode cross-sectional. Jumlah kapal yang diperiksa 12 kapal dan yang positif larva 3 kapal. Kepadatan larva HI 25\%, CI $4.71 \%$ dan BI 41.66\%. Simpulan:Pada penelitian ini ditemukan larva Aedes spp serta kepadatan larva didapatkan memiliki risiko penyebaran vektor sedang diatas kapal yang bersandar di Pelabuahan Laut Samudera Bitung Sulawesi Utara sehingga disarankan untuk melakukan kegiatan penyuluhan sanitasi kapal yang baik kepada ABK kapal.
\end{abstract}

Kata kunci: aedes spp, pelabuhan, kapal, house index, container index, breteau index

Penyakit infeksi merupakan jenis penyakit yang paling banyak diderita oleh penduduk di negara berkembang, termasuk di Indonesia. Penyakit infeksi disebabkan oleh patogen mikroorganisme, seperti bakteri, virus, parasit atau jamur. ${ }^{1}$ Penyebaran penyakit infeksi dapat terjadi melalui hewan misalnya kucing, anjing, kuda, reptil, tikus, kelinci, musang, burung atau unggas, serta juga ada dari jenis-jenis serangga. ${ }^{2}$ Penyebaran penyakit infeksi melalui vektor serangga khususnya nyamuk sering dijumpai hampir semua tempat. Penyakit yang ditularkan oleh gigitan 
nyamuk misalnya penyakit Demam Berdarah Dengue (DBD), Chikungunya, Demam Kuning (yellow fever), Zika, dan penyakit virus lainnya. ${ }^{3}$

Sekitar 2,5 miliar orang atau setara dengan $40 \%$ dari populasi dunia, hidup di daerah dimana terdapat risiko transmisi DBD. Penyakit DBD endemik di seratus negara di Asia Pasifik, Amerika Serikat (AS), Afrika, dan Karibia. World Health Organization (WHO) memperkirakan bahwa terjadi 50 sampai seratus juta kasus infeksi setiap tahun, diantaranya 500.000 kasus DBD dan 22.000 orang meninggal dunia karena DBD, dengan sebagian besarnya adalah anak-anak. ${ }^{4}$

Nyamuk Aedes aegypti (Ae. aegypti) merupakan nyamuk yang berperan dalam penyebaran virus yang menyebabkan penyakit DBD, chikungunya, demam kuning (yellow fever), dan zika. ${ }^{5}$ Nyamuk Ae. aegypti tersebar luas di wilayah tropis dan subtropis Asia Tenggara, seperti di Indonesia serta nyamuk Aedes albopictus tersebar kearah kepulauan Afrika Timur, Filipina dan beberapa kawasan Asia. ${ }^{6}$

Sulawesi Utara (Sulut) merupakan provinsi yang banyak memiliki objek wisata, sehingga di Sulut banyak kedatangan wisatawan lokal maupun mancanegara. Wisatawan atau barang dagangan dapat masuk melalui pelabuhan laut dan bandar udara. Secara tidak langsung, ini menjadi pintu masuk penyakit-penyakit dari berbagai wilayah, misalnya penyakit DBD, Chikungunya, Demam Kuning (yellow fever), Zika yang dapat ditularkan oleh vektor. Vektor berupa nyamuk Aedes spp dapat berkembang biak di atas kapal misalnya ditempat penampungan-penampungan air, sehingga dapat terjadinya transmisi vektor dari wilayah satu ke wilayah lainnya.

Pelabuhan Laut Samudera Bitung berada di Kota Bitung, Sulut. Secara geografis Pelabuhan Bitung berada pada posisi yang strategis karena menghadap Selat Lembeh yang memenuhi syarat kedalaman, ketenangan gelombang dan angin sehingga aman untuk bersandar bagi kapal-kapal dengan berbagai ukuran yang menunjang sebagai alat transportasi laut serta perdagangan ekspor dan impor. ${ }^{7}$ Sehingga disinilah merupakan salah satu faktor terjadinya penyebaran virus-virus penyakit melalui berbagai jenis vektor yang berasal dari berbagai daerah.

Berdasarkan latar belakang di atas, penulis tertarik melakukan penelitian mengenai survei larva Aedes spp di atas kapal yang bersandar di Pelabuhan Laut Samudera Bitung Sulawesi Utara

\section{METODE PENELITIAN}

Penelitian ini merupakan penelitian deskriptif dengan menggunakan metode cross-sectional. Penelitian ini dilakukan di Pelabuhan Laut Samudera Bitung Sulawesi Utara dan di Laboratorium Parasitologi Fakultas Kedokteran Universitas Sam Ratulangi Manado pada bulan Oktober sampai Desember 2016. Subjek penelitian larva Aedes spp di penampunganpenampungan air yang ada di atas kapal yang bersandar di Pelabuhan Laut Samudera Bitung. Sampel penelitian diambil dengan cara Single Larva.

\section{HASIL PENELITIAN DAN BAHASAN}

Berdasarkan hasil penelitian yang telah dilakukan di Pelabuhan Laut Samudera Bitung selama 8 kali kunjungan pada bulan Oktober-November 2016 didapatkan 12 kapal yang bersandar (Tabel 1) terdiri dari kapal yang berjenis kapal motor penumpang, kapal motor barang, serta kapal motor penyebrangan. Dari 12 kapal yang bersandar, 3 kapal penumpang dari Indonesia didapatkan larva Ae. aegypti. Untuk kapal asing tidak ditemukan satupun larva, karena pada kapal asing tempat penampungan - penampungan air tertutup rapat sehingga tidak ada tempat untuk nyamuk berkembangbiak dan juga kapal asing memiliki standar operasional yang ketat untuk sanitasi di atas kapal. 
Data kapal yang bersandar di Pelabuhan Laut Samudera Bitung

Tabel 1. Kapal yang diperiksa di Pelabuhan Laut Samudera Bitung

\begin{tabular}{|c|c|c|c|}
\hline No & $\begin{array}{l}\text { Nama } \\
\text { Kapal }\end{array}$ & Jenis Kapal & $\begin{array}{c}\text { Asal } \\
\text { Kapal }\end{array}$ \\
\hline 1 & S. N 51 & $\begin{array}{l}\text { Kapal Motor } \\
\text { Penumpang }\end{array}$ & INA \\
\hline 2 & S & $\begin{array}{l}\text { Kapal Motor } \\
\text { Penumpang }\end{array}$ & INA \\
\hline 3 & S. N 38 & $\begin{array}{l}\text { Kapal Motor } \\
\text { Penumpang }\end{array}$ & INA \\
\hline 4 & T. P 07 & $\begin{array}{l}\text { Kapal Motor } \\
\text { Barang }\end{array}$ & FLP \\
\hline 5 & S. S & $\begin{array}{l}\text { Kapal Motor } \\
\text { Barang }\end{array}$ & VTM \\
\hline 6 & J. A IV & $\begin{array}{l}\text { Kapal Motor } \\
\text { Barang }\end{array}$ & SGP \\
\hline 7 & B & $\begin{array}{l}\text { Kapal Motor } \\
\text { Penyebrangan }\end{array}$ & INA \\
\hline 8 & L. B & $\begin{array}{l}\text { Kapal Motor } \\
\text { Penyebrangan }\end{array}$ & INA \\
\hline 9 & $\mathrm{~T}$ & $\begin{array}{l}\text { Kapal Motor } \\
\text { Penyebrangan }\end{array}$ & INA \\
\hline 10 & D. P & $\begin{array}{l}\text { Kapal Motor } \\
\text { Barang }\end{array}$ & INA \\
\hline 11 & T. P 03 & $\begin{array}{l}\text { Kapal Motor } \\
\text { Barang }\end{array}$ & INA \\
\hline 12 & B. $\mathrm{M}$ & $\begin{array}{c}\text { Kapal Motor } \\
\text { Barang }\end{array}$ & INA \\
\hline
\end{tabular}

Data jumlah kapal dengan hasil positif atau negatif mengandung larva

Pada Tabel 2 didapatkan bahwa ada 3 kapal $(25 \%)$ yang positif larva serta ada 9 kapal yang negatif tanpa larva. Penelitian ini sejalan dengan penelitian yang dilakukan Nirwan dkk dalam penelitiannya menyatakan bahwa dari 139 kapal yang diperiksa, terdapat 32 kapal $(23 \%)$ yang positif larva. ${ }^{8}$ Survei yang telah dilakukan dalam penelitian ini faktor yang mendukung didapatkan larva di atas kapal karena disebabkan oleh perilaku dari anak buah kapal (ABK) yang kurang memperhatikan sanitasi dari kapal tersebut, misalnya kurang memperhatikan genangan air yang ada serta tempat-tempat penampungan air yang berada di atas kapal sehingga bisa menjadi tempat perindukan dari larva. Menurut Turbowo dkk dalam penelitiannya menyatakan bahwa dari 244 kapal yang diperiksa, terdapat 80 kapal $(33 \%)$ yang positif dengan larva. ${ }^{6}$ Perbedaan yang terjadi antara penelitian ini dengan penelitian yang telah dilakukan oleh Turbowo dkk kemungkinan dipengaruhi oleh jumlah sampel serta waktu kunjungan di pelabuhan pada saat penelitian.

Tabel 2. Jumlah kapal yang postif atau negatif larva

\begin{tabular}{ccc}
\hline Kapal & Jumlah & $(\%)$ \\
\hline+ & 3 & $25 \%$ \\
- & 9 & $75 \%$ \\
Jumlah & 12 & $100 \%$ \\
\hline
\end{tabular}

\section{Data jumlah kontainer positif} mengandung larva

Pada Tabel 3 ditemukan 5 kontainer dengan larva Ae. aegypti dan ada 1 kontainer dengan larva nyamuk lain. Penelitian ini sejalan dengan penelitian yang dilakukan Ahmad dkk pada perimeter area pelabuhan Kota Gorontalo dengan jumlah 6 kontainer yang positif larva $A e$. aegypti. $^{9} \quad$ Pada penelitian ini juga ditemukan larva selain Ae. aegypti yaitu larva dari nyamuk lain (Culex sp).

Tabel 3. Jumlah kontainer dengan larva yang positif.

\begin{tabular}{ccc}
\hline Jenis & Jumlah & $(\%)$ \\
& Kontainer & $(\%$ \\
\hline Aedes aegypti & 5 & $83 \%$ \\
Nyamuk lain & 1 & $17 \%$ \\
Jumlah & 6 & $100 \%$ \\
\hline
\end{tabular}

Thete dan Shinde menyatakan dari 1893 larva yang ditemukan, kontainer dari plastik menunjukan angka larva terbanyak (dalam rumah $80 \%$ dan luar rumah $68 \%$ ) diikuti dengan pot tanah liat, ban, kaleng, tangki air dari semen dan lain-lain. Ae. aegypti dan Culex sp berkembangbiak pada semua jenis kontainer yang ada di luar rumah. $^{10}$ Menurut Robinson habitat larva nyamuk lain dapat hidup berdasarkan lokasi serta juga musim. Selain itu juga 
nyamuk sering terdapat di genangan genangan air ataupun tempat - tempat penampungan air yang bersih maupun kotor, serta ditempat yang gelap. ${ }^{11}$
Pada Tabel 4 didapatkan bahwa sebagian besar larva ditemukan di bukan tempat penampungan air yaitu di lekukan terpal $(2,8 \%)$.

\section{Data perindukan TPA dan bukan TPA larva Aedes spp}

Tabel 4. Jenis tempat TPA dan bukan TPA larva Aedes spp

\begin{tabular}{|c|c|c|c|c|c|}
\hline No & $\begin{array}{c}\text { Jenis Tpa Dan } \\
\text { Bukan Tpa }\end{array}$ & $\begin{array}{c}\text { Yang } \\
\text { Diperiksa }\end{array}$ & $\begin{array}{c}\text { Jumlah } \\
\text { Positif } \\
\text { Larva }\end{array}$ & $\begin{array}{c}\text { Nilai } \\
\text { Persentase Dari } \\
\text { Jumlah Positif } \\
\text { Larva } \\
\end{array}$ & $\begin{array}{c}\text { Total Hasil } \\
\text { Persentase Pada } \\
\text { Tpa Dan Bukan } \\
\text { Tpa } \\
\end{array}$ \\
\hline 1 & Bak Mandi & 6 & 1 & $16.7 \%$ & $0.9 \%$ \\
\hline 2 & $\begin{array}{l}\text { Lekukan } \\
\text { Terpal }\end{array}$ & 8 & 3 & $37.5 \%$ & $2.8 \%$ \\
\hline 3 & $\begin{array}{l}\text { Dalam Celah } \\
\text { Mesin Katrol }\end{array}$ & 1 & 1 & $100 \%$ & $0.9 \%$ \\
\hline 4 & Ember & 49 & 0 & $0.0 \%$ & $0.0 \%$ \\
\hline 5 & Kaleng & 15 & 0 & $0.0 \%$ & $0.0 \%$ \\
\hline 6 & Tangki Air & 3 & 0 & $0.0 \%$ & $0.0 \%$ \\
\hline 7 & Ban Bekas & 9 & 0 & $0.0 \%$ & $0.0 \%$ \\
\hline 8 & $\begin{array}{l}\text { Genangan Air } \\
\text { di Lantai }\end{array}$ & 5 & 0 & $0.0 \%$ & $0.0 \%$ \\
\hline 9 & Wajan Bekas & 2 & 0 & $0.0 \%$ & $0.0 \%$ \\
\hline 10 & Drum Air & 8 & 0 & $0.0 \%$ & $0.0 \%$ \\
\hline & Total & 106 & 5 & $15.4 \%$ & $4.7 \%$ \\
\hline
\end{tabular}

Pada Tabel 4 terdapat 4 kontainer tempat penampungan air (TPA) dan 6 kontainer bukan TPA. Dari 10 TPA dan bukan TPA yang diperiksa, didapatkan ada 4 larva yang ditemukan di kontainer bukan TPA yaitu di lekukan terpal $(37,5 \%)$ dan di dalam celah mesin katrol $(100 \%)$ dan 1 larva ditemukan di TPA yaitu bak mandi $(16,7 \%)$. Dari survei yang dilakukan, maka didapatkan larva Ae. aegypti kebanyakan berada di tempat bukan TPA seperti lekukan terpal serta dalam celah mesin katrol. Ini disebabkan karena pada tempattempat penampungan air yang ada di atas kapal tertutup serta rata-rata $\mathrm{ABK}$ untuk melakukan kegiatan memasak atau mandi mereka menggunakan air yang langsung dari kran air yang mengalir dari penampungan air yang tersedia di kapal. Penelitian ini sejalan dengan penelitian yang dilakukan Turbowo dkk dalam penelitiannya menyatakan kapal penumpang umumnya untuk tempat penampungan air di kapal hampir tidak ada serta kamar mandi dan wc dilengkapi dengan kran air. ${ }^{6}$

Berdasarkan hasil pengukuran kepadatan larva, didapatkan House Index (HI) sebesar 25\%, Cointainer Index (CI) sebanyak $4.71 \%$, dan Breatau Index (BI) sebanyak $41.66 \%$. Kepadatan larva yang diukur dengan menggunakan tabel density figure didapatkan density figure yaitu 4, artinya risiko transmisi sedang untuk vektor DBD, chikungunya, demam kuning, atau virus lainnya. Penelitian ini sejalan dengan penelitian yang dilakukan Nirwan dkk dalam penelitiannya menyatakan tingkat kepadatan nyamuk di kapal dalam kategori density figure 4 yang merupakan risiko transmisi penularan sedang untuk vektor DBD. ${ }^{8}$

Berdasarkan hasil penelitian ini didapatkan kapal yang bersandar di pelabuhan bisa menjadi tempat perindukan dari larva nyamuk dan sebagai alat untuk 
transmisi nyamuk dari daerah yang endemis ke daerah non endemis. Larva nyamuk Ae. aegypti kemungkinan bisa mengandung virus dengue yang didapatkan dari induknya yang sudah terinfeksi virus dengue sebelumnya. Menurut penelitian yang dilakukan oleh Hartanti dkk dari 15 larva yang dikembangbiakan menjadi nyamuk dewasa didapatkan 3 nyamuk $A e$. aegypti yang telah terinfeksi virus dengue. $^{12}$ Menurut Eldridge ada satu cara transmisi virus yang disebut transmisi transovarial yang terjadi ketika nyamuk betina yang telah terinfeksi virus bertelur dan menghasilkan telur yang mengandung virus dengue. ${ }^{13}$ Sehingga kapal - kapal ini bisa menjadi salah satu alat transmisi nyamuk untuk menyebarkan virus.

\section{SIMPULAN}

Pada penelitian yang dilakukan pada bulan Oktober-November 2016 di Pelabuhan Laut Samudera Bitung Sulawesi Utara ditemukan larva Aedes spp pada kapal yang bersandar. Kepadatan larva Aedes spp di atas kapal yang bersandar di Pelabuhan Laut Samudera Bitung Sulawesi Utara didapatkan House Index (H.I) 25\%, Container Index (C.I) $4.71 \%$ dan Breteau Index (B.I) $41.66 \%$

\section{SARAN}

1. Perlu dilakukan penyuluhan mengenai sanitasi kapal yang baik kepada para ABK.

2. Untuk Instansi yang terkait dapat memperketat lagi pemeriksaan kapal pada sistem sanitasi agar bisa mencegah kapal menjadi alat transmisi dari vektor.

3. Perlu dilakukan penelitian lanjutan dengan jumlah kapal dan waktu kunjungan ke pelabuhan lebih banyak.

\section{DAFTAR PUSTAKA}

1. World Health Organization. Infectious Disease. [Online]. [cited 2016 Sep 13]. Available from: http://www.who.int/topics/infectious_di seases/en/
2. GrØndalen J, Sævik B, SØrum. Companion Animals as Reservoir for Zoonotic Diseases. EJCAP. 2008;18:213-21.

3. Centers for Disease Control and Prevention. Zika Virus. [Online]. [cited 2016 Sep 13]. Available from: http://www.cdc.gov/zika/vector/range.h tml

4. Centers for Disease Control and Prevention. Dengue Epidemiology [Online]. [cited 2016 Sep 13]. Available from http://www.cdc.gov/dengue/epidemiolo gy/

5. Centers for Disease Control and Prevention. Dengue and Aedes aegypti Mosquito. [Online]. [cited 2016 Sep 13]. Available from: https://www.cdc.gov/dengue/resources/ 30jan2012/aegyptifactsheet.pdf

6. Hasanuddin University. Faktor yang Mempengaruhi Keberadaan Larva Aedes aegypti di Kapal Dalam Wilayah Pelabuhan Makasar. [Online]. [cited 2016 Sep 15]. Available from : http://repository.unhas.ac.id/handle/123 456789/6988

7. Salim Z, Mychelisda E, Rahmayanti AZ. Bitung sebagai Pelabuhan Hub Internasional.Warta Pengkajian Perdagangan. 2015;3:19-20.

8. Nirwan, Arsin AA, Ishak H. Faktor yang Berhubungan Dengan Keberadaan Vektor Aedes Aegypti di Kapal Dalam Wilayah Pelabuhan Makassar. Jurnal MKMI. 2010;6:130

9. Ahmad SD, Boekoesoe L, Prasetya. Survey Jentik Aedes Aegypti Pada Perimeter Area Di Pelabuhan Kota Gorontalo.

10. Thete KD, Shinde LV. Survey of Container Breeding Mosquito Larvae in Jalna City (M.S) India. Biological Forum An Internasional Journal. 2013;5:126.

11. Robinson WH. Urban Insect And Arachnids A Handbook of Urban Entomology. Cambridge University Press. 2005. p. 166-167.

12. Hartanti MD, Suryani, Tirtadjaja IA. Dengue Virus Transovarial Transmission by Aedes aegypti. Universa Medicina. 2010;29:66-67

13. Eldrige BF. Biology and Control of Mosquitoes. California Department of Public Health. 2008. p. 8, 17. 